https://doi.org/10.22364/htqe.2019.10

\title{
THE QUALITY OF HOME ECONOMICS AND TECHNOLOGIES. OPINIONS OF HOME ECONOMICS AND TECHNOLOGIES TEACHERS
}

\author{
Māra Urdzin,a-Deruma \\ University of Latvia, Latvia \\ Mārīte Kokina-Lilo \\ University of Latvia, Latvia \\ Gunta Treimane \\ University of Latvia, Latvia
}

\begin{abstract}
Realising the competence based education reform in Latvia in which Home Economics and Technologies is being transformed into Design and Technology, it is essential to ascertain the subsequent opinions of Home Economics and Technologies teachers. The goal of this study is to explore the opinions of Latvian Home Economics and Technologies teachers on learning and teaching different material working technologies in general education schools, finding out what teachers understand as a high quality learning and teaching process and compare it to public opinion. This study features the questionnaire method $(\mathrm{N}=155)$. Results are analysed both qualitatively and quantitatively. Results show that, while Home Economics and Technologies teachers share similar opinions with the public, recognising the competency of teachers and the quality and supply of materials and technologies in workshops as crucial in first-rate teaching and learning of Home Economics and Technologies, teachers put greater value on the subject content, skills and interest of students. Few respondents view success in competitions and carefully considered teaching methods as criteria for quality. Both teachers and society share the opinion that practical skills that can be used in everyday life are the most important contribution to the education of students. Few respondents noted career education and learning about traditional culture as important. In contrast to public opinion, most respondents do not think all optional student chosen topics should be mandatory for all pupils to the same degree.
\end{abstract}

Keywords: education quality, home economics and technology, home economics and technology teacher. 


\section{Introduction}

Currently Latvia is going through a reform in general education and the education of teachers, which affects the teaching and learning of material working technologies in basic education schools and teacher's education in universities. Finland (2014) and Sweden (2018) have also signed new basic education regulating documents that have changed the approach to craft education in basic education schools and in the higher education of teachers (Vahtivuori-Hanninen, Halinen, 2014; Läroplan för..., 2011).

While researching possibilities of improvement in Home Economics and Technologies as a school subject, Kūla-Braže (2015) provides three approach scenarios: The developmental Home Economics and Technologies scenario, Home Economics and business scenario and the Home Economics and applied arts scenario, involving the study of traditional cultural heritage.

Nowadays in Finland craft education in schools is seen as a way to help people understand sustainable consumerism and individual satisfaction, meanwhile developing skills and creating something by their own hands. A great emphasis is put on students developing skills in projecting and creating sustainable, meaningful, useful, aesthetically pleasing products of good quality, thus striving towards a holistic craftmaking process (PorkoHudd, Pöllänen, 2018).

Much like in Latvia (Regulations on..., 2018), in Finland it is a challenge developing technological competency and entrepreneur education connected to design and material working. (Porko-Hudd, Pöllänen, 2018).

In their research Räisänen and Kokko (2019) raise awareness of the possibilities of learning traditional culture related to Finland's craft education. While researching the development of craft education in Sweden, Borg (2018) states that in the beginning the most important was the product or piece created by pupils, which is determined by the teacher according to O. Salomon's approach. From 1969 to 1994 the learning of crafting techniques was the most important, and from 1994 the new curriculum determined the process itself as the most important. Since 2018 the essential part of craft education is acquiring knowledge, with the curriculum divided in 4 main topics: The material, tools and techniques of Sloyd, The working processes in Sloyd, The cultural and aesthetic forms of expression in Sloyd, Sloyd in the society (Läroplan för..., 201111). Borg (2018) emphasises the uniqueness of the subject: "while the young people work, they train their problem solving, their endurance, their brain, eyes and hands in a very special combination which can never be learned by reading a book." Uniqueness of this subject is also stressed by Johansson and Andersson $(2017,107)$ "School sloyd lessons offer a kind of learning that 
differs from many school subjects in that parts of the knowledge are practised and made visible through making a physical sloyd object".

Research done by Root-Bernstein, Van Dyke, Peruski and Root-Bernstein (2019) concludes that integrating art, craft and design into the Science, Technology, Engineering, Math, \& Medicine (STEMM) curriculum can be an effective way to improve study results in STEMM subjects. The goal of this study is to explore the opinions of Latvian Home Economics and Technologies teachers on learning and teaching different material working technologies in general education schools, finding out what teachers understand as a first-rate learning and teaching process and compare it to public opinion.

\section{Methodology and Materials}

This study is based on a previous study exploring the Latvian public opinion on the quality of Home Economics and Technologies education. (Urdzina-Deruma, Kokina-Lilo, 2019). This study uses the questionnaire method. The questionnaire consists of open-ended and closed-ended questions. The results are analysed quantitatively and qualitatively, and compared to the results of the previous study. Answers to closed-ended questions are analysed quantitatively. Answers to open-ended questions are summarised in tables and grouped according to categories, and later analysed quantitatively. (Kroplijs, Raščevska, 2010). 155 respondents questioned were Home Economics and Technologies teachers representing the whole country of Latvia: $40 \%$ live in the countryside, $39 \%$ in small cities, $6 \%$ in Riga and 15\% in other large cities. Respondents make up $3,3 \%$ of all Latvian Home Economics and Technologies teachers. $85 \%$ of the respondents are female, $15 \%$ male. Respondents were coded, giving each respondent a number from R1 to R155.

\section{Results and Discussions}

Responding to the question, if all Home Economics and Technologies topics should be covered by all pupils without the option to choose, most teachers (74\%) state that not all topics should be mandatory for all pupils and they should be given an option to choose topics. $18 \%$ agree that all Home Economics and Technologies topics should be studied by all pupils without option to choose, and $8 \%$ of respondents give different answers, see Fig. 1. Compared to Latvian public opinion, it can be concluded that percentually there is a large difference, as only $48 \%$ of the public think pupils should be allowed to choose what topics to study in Home Economics and Technologies, whereas $41 \%$ of respondents think all topics should be 
covered without options. $11 \%$ of respondents from the public give different answers (Urdzin,a-Deruma, Kokina-Lilo, 2019).

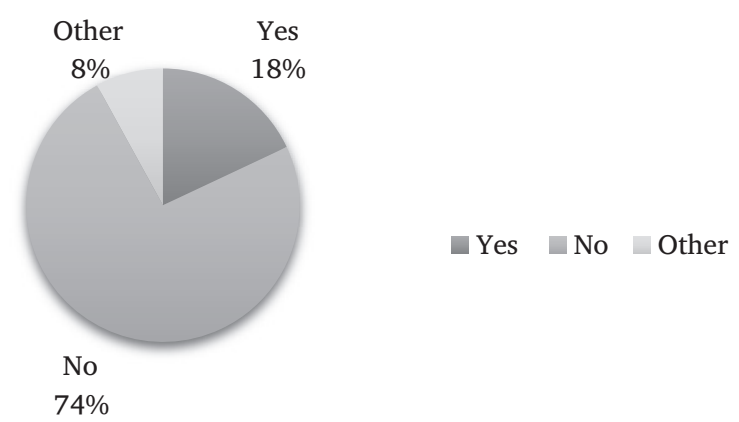

Figure 1. Answers to the question whether all Home Economics and Technologies topics should be covered by all pupils without option to choose

Answers to the question concerning categories that represent quality acquisition of Home Economics and Technologies subject, the most popular category mentioned is material and technological supply (29\%). For example, respondent R148 mentions "Materials and supplies of all kinds", respondent R94 answers: "Good materials and supplies, well planned and arranged workshops". Following are categories of the teacher (25\%), skills acquired by pupils (25\%), subject curriculum (19\%) and interested pupils (14\%). For example, respondent R1 answers: "A professional teacher, a motivated student, and quality material supply".

As mentioned in the research done by Page and Thorsteinsson (2018, 42): "There are endless reasons why one should craft, but there can be no crafting without a willingness to learn; a desire to be and a passion for using one's hands; a love of being sociable and a longing to be connected to the world we live in".

Much like studying the opinion of the public, there are comparatively few answers mentioning categories such as success in competitions, exhibitions, new technologies, product creation, teaching methods, see Fig. 2.

Researching what Home Economics and Technologies teachers consider a masterful study subject teacher, percentually the most popular answer is a professional and competent teacher $(27 \%$ of 37 respondents that mention the teacher as impactful on the quality of the subject). The next percentually most popular answer is "a teacher that can raise interest" (22\%). $14 \%$ of respondents mention qualities of creativity and engagement in a teacher, see Fig. 3. 


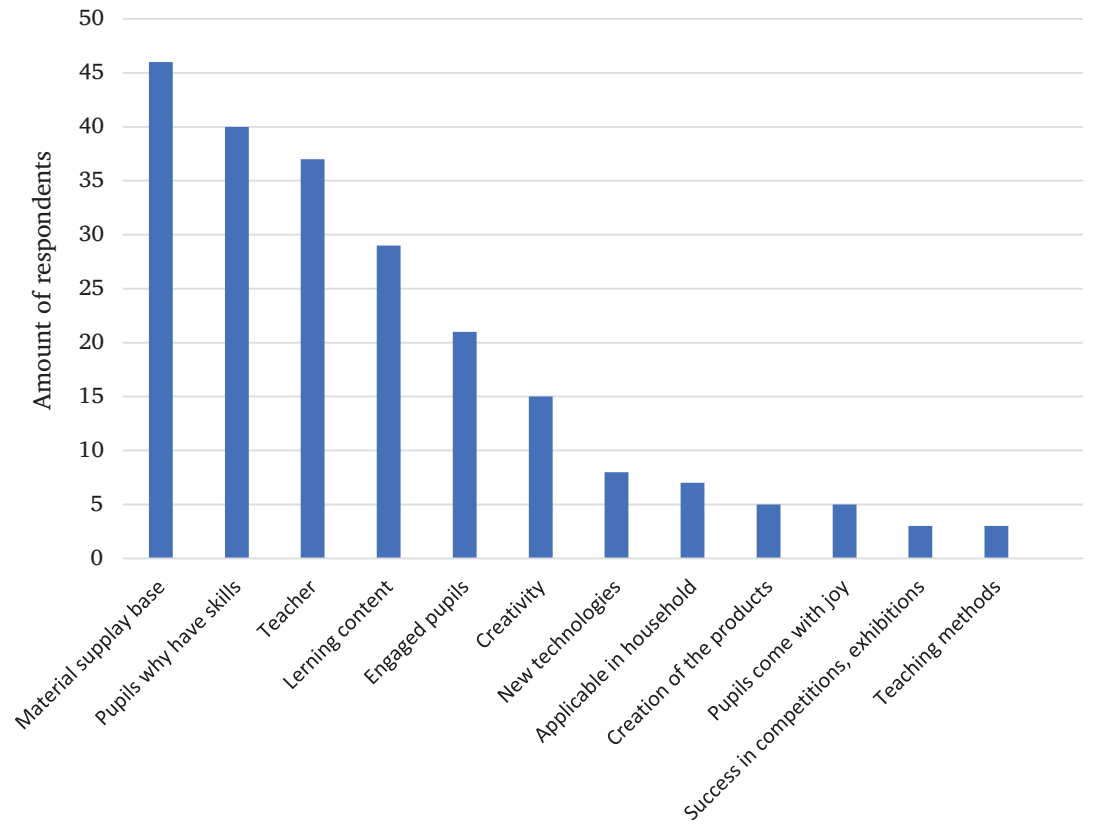

Figure 2. Respondents' views concerning categories that represent qualitative acquisition of Home Economics and Technologies subject

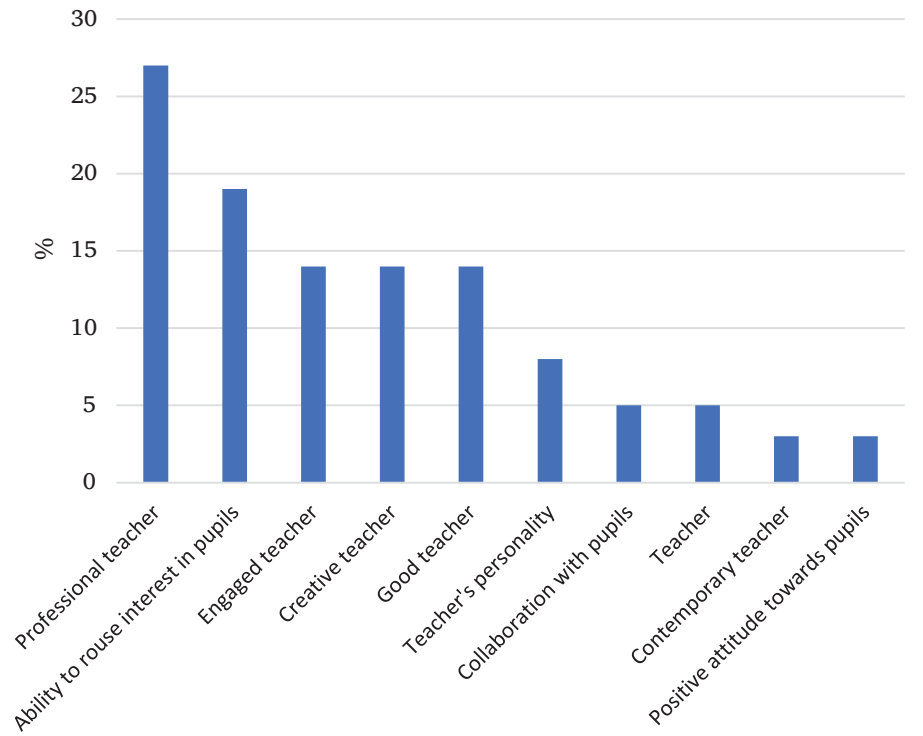

Figure 3. Respondents' views concerning the teacher- provider of quality Home Economics and Technologies subject 
Comparing the opinion of teachers to opinions of the public, it can be concluded that teachers put greater value on the skills acquired by students, along with the material supply and the teacher, whereas the public is mostly oriented towards the importance of the teacher (32\%) and the material supply basis (24\%). Calculating the Pearson correlation coefficient, rapr $=0,711>\mathrm{rkr}=0,532$ (Correlation is significant at the 0.05 level (2-tailed)), it can be concluded that there is no statistically significant difference between the opinions of teachers and the public considering quality of the subject. The greatest difference percentually between teachers' and society's opinion is on the importance of subject curriculum see Fig. 4.

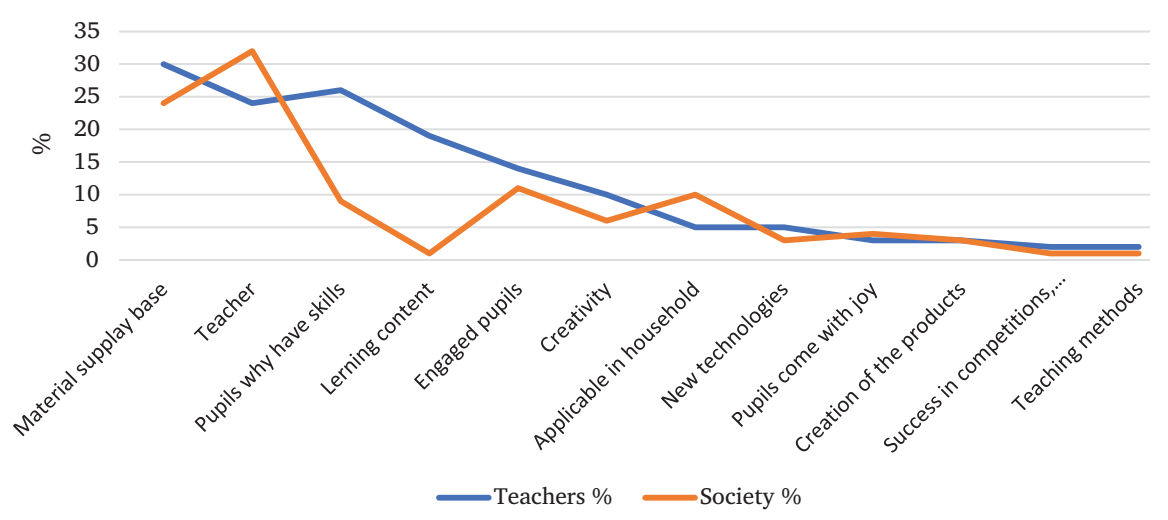

Figure 4. Respondents' (society and teachers') views concerning categories that represent qualitative acquisition of Home Economics and Technologies subject

Responses to the question "What is the greatest benefit pupils gain by studying the curriculum of the Home Economics and Technologies subject?" are similar in both groups of respondents. Most respondents (71\%) consider practical skills acquired as the most important as $37 \%$ of respondents view practical skills and 34\% of respondents view useful skills for everyday life as the greatest benefit. For example, respondent R65 writes: "Practical life skills - make a meal for yourself and others, knit mittens like no one else has, create gift packaging etc." Another respondent R134 writes that "This is the most unique school subject in which a pupil is prepared for real life theoretically and practically. He is competent in being self-sustainable, sustaining a home, he or she has acquired table manners and the knowledge and skills to prepare meals (..). This subject provides the opportunity for pupils to experiment and do research in almost every lesson, to justify their results; Home Economics practically extends all other school subjects: Math, Art and spatial thinking, 
Physics, Chemistry, languages, Geography and Economics, the list goes on. Learning Home Economics and Technologies a pupil acquires comprehensive development and positive emotions from their results."

$15 \%$ of respondents mention the greatest benefit is the comprehension of the life cycle of things from an idea to the result. Creativity is mentioned by $14 \%$, fine finger motor skill development is noted by $13 \%$, planning by $9 \%$ and mind and brain activity is mentioned by $8 \%$. Taste in style is noted as the most beneficial by $7 \%$ of respondents, developing patience $-6 \%$. Only $5 \%$ of respondents consider the study of traditional cultural heritage as the most beneficial and only $3 \%$ of respondents mention future career awareness, see Fig. 5.

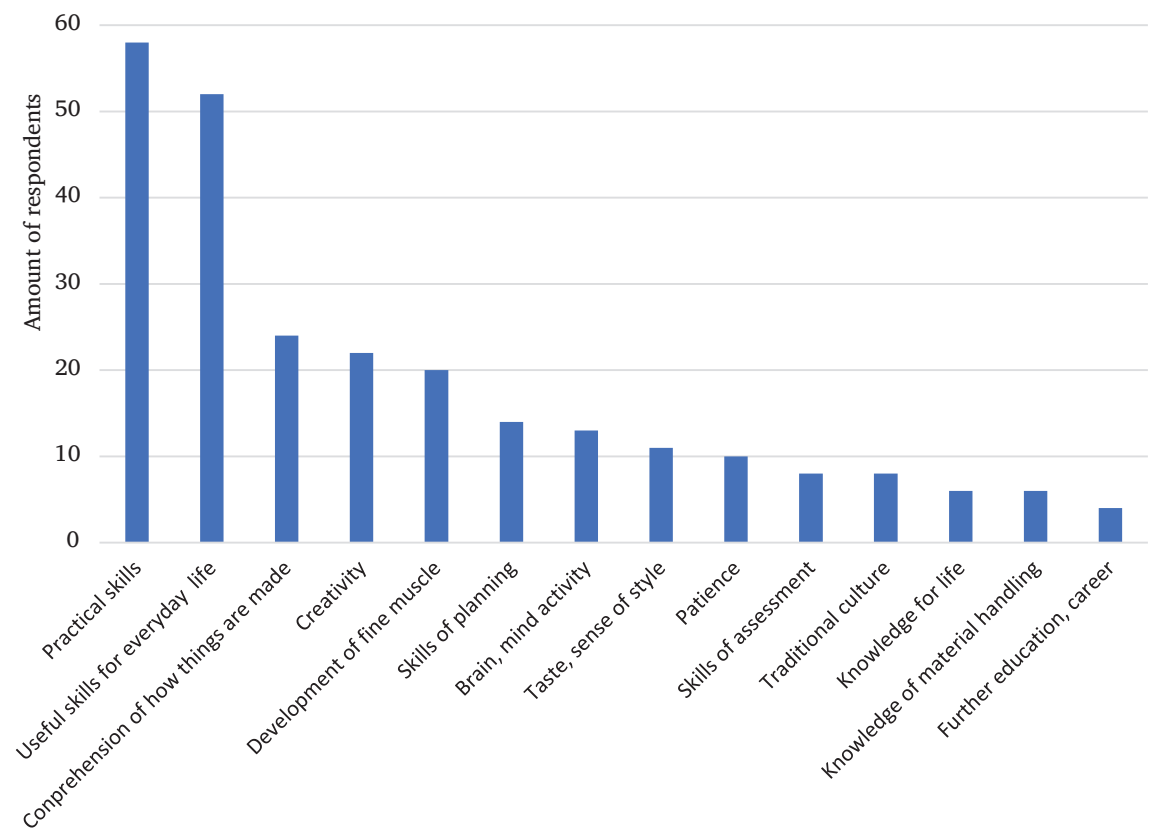

Figure 5. Respondents' views on the main benefits pupils gain by learning the content of the Home Economics and Technologies subject

Comparing society's opinion with the opinion of teachers it can be concluded that both groups share their views on the main benefits of studying Home Economics and Technologies. Public opinion is mostly dominated by practical skills and everyday life skills. The greatest percentual difference is in the category of comprehension of how things are made, as $15 \%$ of teachers consider it to be the greatest benefit for pupils, whereas only $5 \%$ of society share this opinion. Percentually teachers value more the impact of Home Economics and Technologies on fine finger motor skills, brain 
development, creativity and developing patience (see Fig. 6). Altogether there is no statistically significant difference as the Pearson correlation coefficient is rapr $=0,954>\mathrm{rkr}=0,532$ (Correlation is significant at the 0.05 level (2-tailed)).

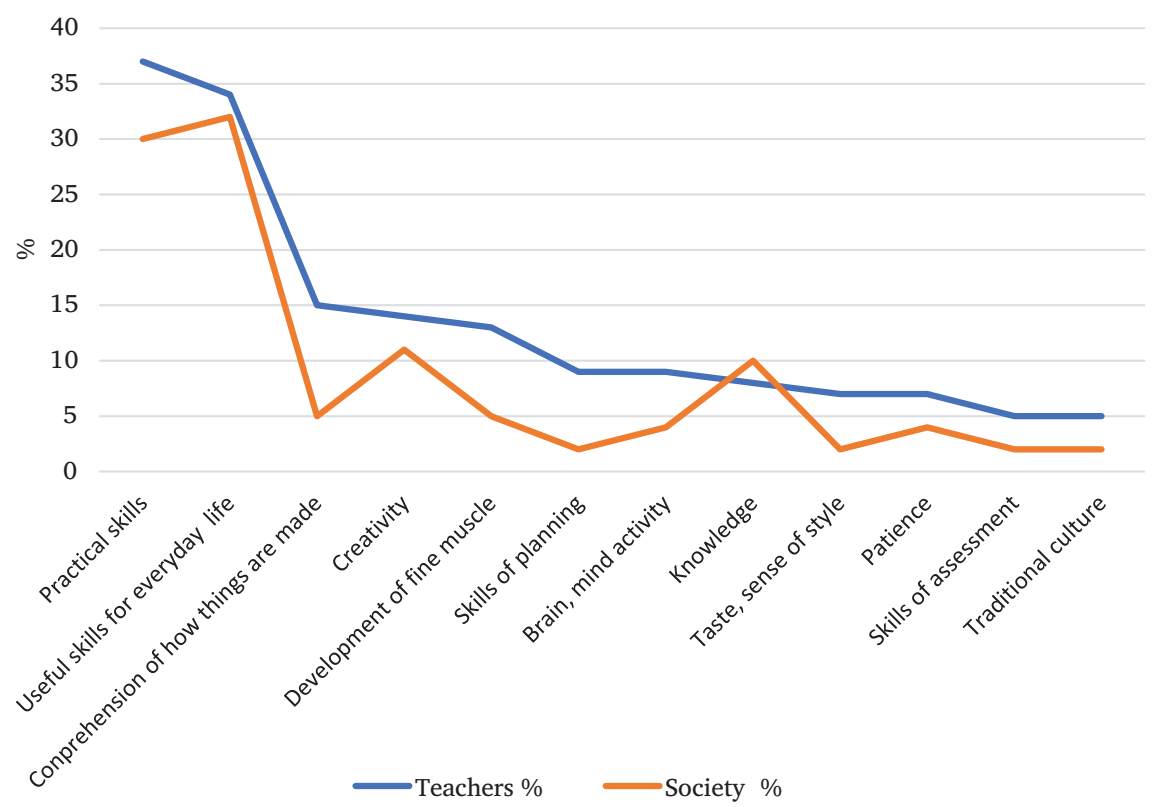

Figure 6. Respondents' views on the main benefits pupils gain by learning the content of the Home Economics and Technologies subject

When answering what should be changed in the subject, the most popular answer category is subject content and curriculum mentioned by 61 respondent, summing up to $40 \%$ of answers. Respondents point out that Home Economics and Technologies curriculum should be adjusted to fit real life needs, for example, learning simple yet practical textile working skills (since nowadays many pupils struggle with handicrafts), accenting healthy nutrition, interior design basics, how to maintain a well-kept house and attire, how to work with various electric appliances, how to calculate material costs, how to turn a defect in to an effect etc. Multiple respondents advise paying more attention to creative works, increasing the variety of crafting techniques learnt. Some mention the need for studying basics of business and entrepreneurship as studying Home Economics and Technologies could encourage deeper comprehension of these subjects. This category of subject content is also the most popular answer among the respondents from general society. Calculating the Pearson correlation coefficient rapr $=0,475<\mathrm{rkr}=0,576$ (Correlation is significant at 
the 0.05 level (2-tailed)), it can be concluded that there is a statistically significant difference between the opinions of teachers and general society. Comparing teachers' opinion to public opinion, teachers greatly emphasise the need to increase the number of lessons (17\%) and improvement of material supply (14\%). $12 \%$ of the public think teaching methods should be improved, whereas only $1 \%$ of teachers share this opinion. 11 respondents teachers $(7 \%)$ and $12 \%$ of society would not change anything. Compared to public opinion (6\%), fewer teachers (1\%) consider division by gender unnecessary. To the question considering workload, both groups share similar answers, where $6 \%$ of the public and $4 \%$ of teachers think it should be decreased, see Fig. 7 .

In comparison with the study on the opinion of students who studied Home Economics and Technologies in exchange programs abroad (UrdzinaDeruma, Šelvaha, 2018), it can be concluded that students see the curriculum and subject content as the greatest area of potential development (19 content classifiers from 49). However, unlike teachers and the general public, students place methodology second (10 content classifiers from 49), followed by improving the availability of materials and supplies ( 9 content classifiers from 49). Results of the study show that after returning from studies abroad and working in school, students improved teaching methods the most (8 content classifiers from 19).

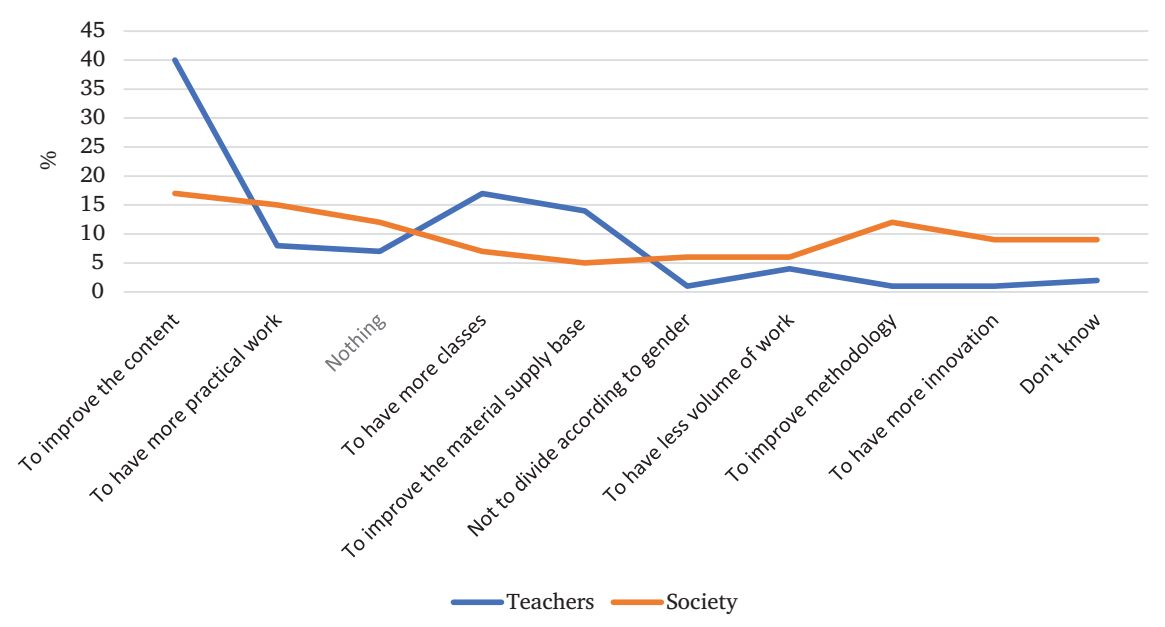

Figure 7. Respondents' views on the development of Home Economics and Technologies subject

Almost half of the respondents mention nutrition and textile technologies as essential to the subject curriculum. Adding the respondents who answered all topics in current curriculum should be covered by all 
students without option, then altogether $2 / 3$ of the respondents consider nutrition and textile technologies as essential (Fig. 8).

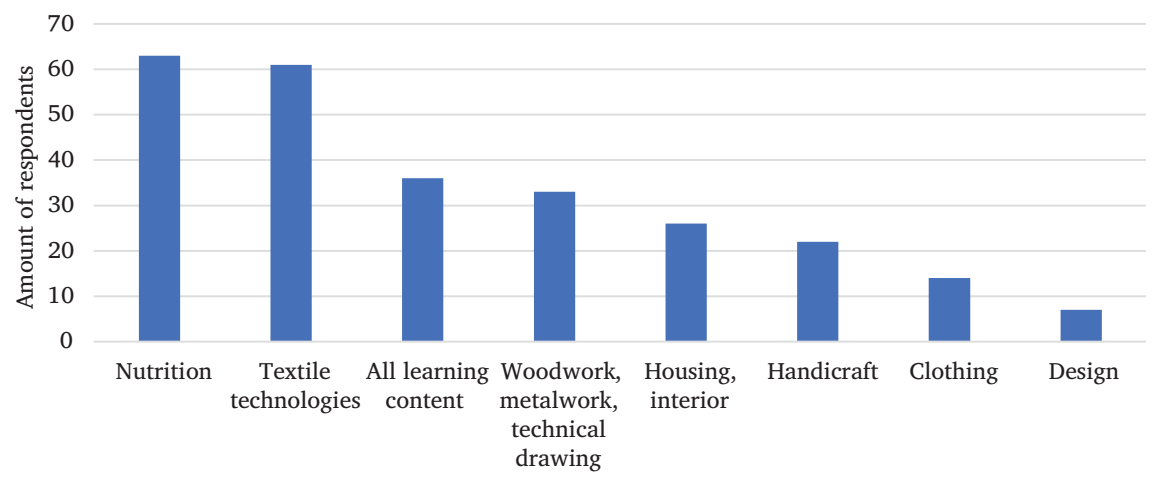

Figure 8. Respondents' views concerning learning topics that should definitely be included in the content of Home Economics and Technologies subject

As for topics that respondents would have liked to study, but did not have the availability during their school years, the most popular techniques are weaving, felting, batik and silk painting, beading and different woodworking techniques, see Fig. 9.

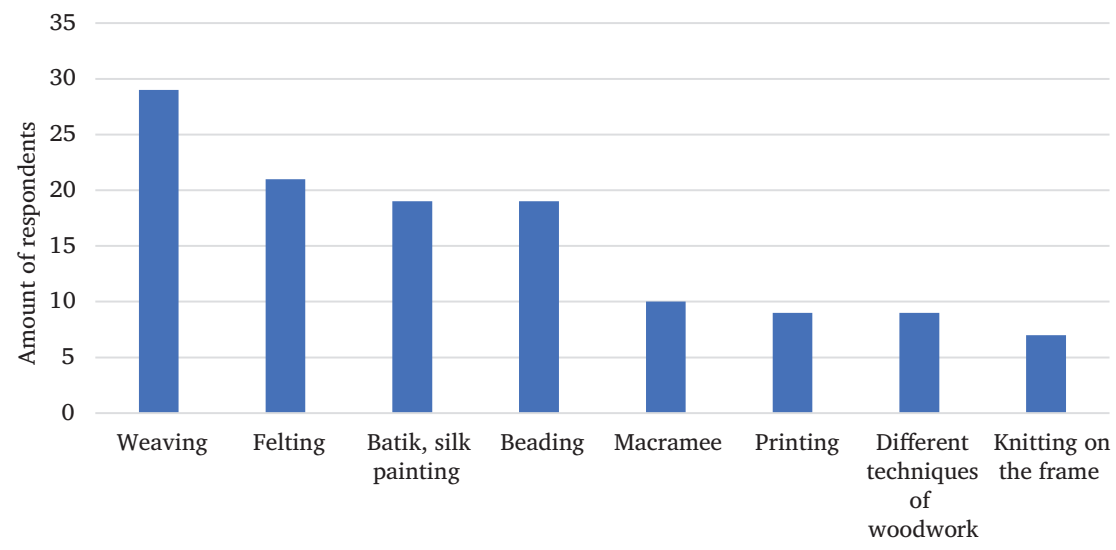

Figure 9. Home Economics topics that respondents would have liked to study during their school years, if it were available 


\section{Conclusions}

Results show that Home Economics and Technology teachers see materially and technologically supplied workshops, acquired skills by the pupils, teacher's competency, subject content and curriculum, as well as the interest of students as the most important elements contributing to high quality learning of Home Economics and Technologies. Few respondents mention success in competitions and thoroughly considered teaching methods as a criteria for quality. Both society and teachers share the opinion that the greatest investment in pupils' education is practical skills and everyday life skills. Few respondents see career education possibilities and learning traditional cultural heritage as important. Only 15\% of respondents consider the understanding of how things are made as the greatest investment in pupils' education. The understanding of how things are made is greatly stressed in the current educational reform in relation to the transformation of the subject Home Economics and Technologies.

Much like the general public, teachers of Home Economics and Technologies consider nutrition as the pivotal topic in the subject, however, textile working is also mentioned. It should be noted that most respondents are female. Men and a significant number of women mention woodworking, metalworking and technical drafting as important. As for topics that respondents would have wanted to study in school but had no possibility to, most responses are weaving, felting, batik, silk painting, beading and different woodworking techniques. Most respondents - teachers (74\%) in contrast to respondents from general society (48\%) do not consider all traditionally optional topics as mandatory for all students.

Results show that, corresponding to the theory about pedagogical models of handicraft education (Pöllänen, 2009), the opinion of Home Economics and Technologies teachers (as well as the opinion of general society) relates to the model "Craft as skill and knowledge building".

\section{References}

Borg, K. (2018). Swedish Sloyd - What happened after Otto Salomon? Bulletin of Institute of Technology and Vocational Education, Nagoya: Nagoya University, 18, 1-4. https:// www.lu.lv/fileadmin/user_upload/lu_portal/apgads/PDF/HTQEd_Daniela/Book-HumanTechnologies-and-Quality-of-Education.pdf ISBN 9789934184000.

Johansson, M., \& Andersson, J. (2017). Learning situations in Sloyd - to become more handy, dexterous and skilful. Techne Series - Research in Sloyd Education and Craft Science A, 24(2), 93-109. Retrieved from https://journals.hioa.no/index.php/techneA/ article/view/1875

Kroplijs, A., \& Raščevska, M. (2010). Kvalitatīvās pētniecības metodes sociālajās zinātnēs [Qualitative research methods in the Social Sciences]. $2^{\text {nd }}$ ed. Riga: RaKa. 
Kūla-Braže, E. (2015). Home economics education development opportunities. Society. integration. education. Proceedings of the International Scientific Conference, [S. 1.], v. 1, 250-257, May 2015. ISSN 2256-0629. Available at: < http://journals.ru.lv/index. php/SIE/article/view/534/308>. Date accessed: 25 june 2019. doi:http://dx.doi. org/10.17770/sie2013vol1.534.

Läroplan för grundskolan, förskoleklassen och fritidshemmet. Reviderad 2018. (2011). Skolverket. Stockholm: Fritzes, 1-302.

Ministru kabineta 2018. gada 27. novembra noteikumi Nr. 747 "Noteikumi par valsts pamatizglītības standartu un pamatizglìtības programmu paraugiem". (2018) [Regulations of the Cabinet of Ministers of November 27, 2018747 "Regulations on National Standard for Basic Education and Models of Basic Education Programs"] Latvija: Ministru Kabinets. Cabinet of Ministers of the Republic of Latvia. Retrieved from https://likumi.lv/doc.php?id = 268342

Page, T., \& Thorsteinsson, G. (2018). The importance and benefits of practicing craft. Bulletin of Institute of Technology and Vocational Education, Nagoya: Nagoya University, $18,32-44$.

Pöllänen, S. (2009). Contextualising craft: Pedagogical models for craft education. International Journal of Art \& Design Education, 28(3), 249-260. doi: 10.1111/j. 1476-8070.2009.01619.x

Porko-Hudd, M., Pöllänen, S., \& Lindfors, E. (2018). Common and holistic crafts education in Finland. Techne Series - Research in Sloyd Education and Craft Science A, 25(3), 26-38. Retrieved from https://journals.hioa.no/index.php/techneA/article/view/3025

Räisänen, R., \& Kokko, S. (2019). Craft education in sustaining and developing craft traditions. Techne Series - Research in Sloyd Education and Craft Science, 26(1), 27-43. Retrieved from https://journals.hioa.no/index.php/techneA/article/view/2911

Root-Bernstein, R., Van Dyke, M., Peruski, A., \& Root-Bernstein, M. (2019). Correlation between tools for thinking; arts, crafts, and design avocations; and scientific achievement among STEMM professionals. Youngmoo E. Kim (Ed.) Proceedings of the National Academy of the Sciences of the United States of America (PNAS). 116 (6), 1910-1917. https://doi.org/10.1073/pnas.1807189116

Urdziņa-Deruma, M., Kokina-Lilo, M., Treimane, G., \& Šelvaha, L. (2018). Latvian public opinion on the quality of home economics and technologies. Human, Technologies and Quality of Education = Cilvēks, tehnologíijas un izglïtibas kvalitāte. Rìga : LU Akadēmiskais apgāds, 2018 pp. 75-94.

Urdziña-Deruma, M., \& Šelvaha, L. (2018). Crafts and Home Economics studies abroad. Students identified differences and suggestions for teacher education in Latvia. International Journal of Smart Education and Urban Society, 9(4), 77-89. DOI: 10.4018/ IJSEUS.2018100107. URL: https://www.igi-global.com/article/crafts-and-homeeconomics-studies-abroad/214056, URL: https://dbh.nsd.uib.no/publiseringskanaler/ erihplus/periodical/info.action?id=488022 ISSN 2574-8254.

Vahtivuori-Hanninen, S., Halinen, I., Niemi H., Lavonen J., \& Liponnen L. (2014). A New Finnish National Core Curriculum for Basic Education (2014) and Technology as an Integrated Tool for Learning Finnish Innovations and Technologies in Schools. A Guide Towards New Ecosystems of Learning. pp. 21-32. DOI: 10.1007/978-94-6209-749-0_2 